\title{
Towards a living agriculture: extension of the notion of agriculture among rural extension agents based on a comprehensive approach to indigenous knowledge in Caldas, Colombia
}

\author{
Rumo a uma agricultura viva: extensão da noção de agricultura entre \\ extensionistas rurais mediante a aproximação compreensiva do \\ conhecimento indígena em Caldas, Colômbia \\ Marlon Javier Méndez Sastoque ${ }^{1}$ (1) \\ 'Departamento de Desarrollo Rural y Recursos Naturales, Facultad de Ciencias Agropecuarias, Universidad de Caldas (UCALDAS), \\ Manizales (Caldas), Colombia. E-mail: marlon.mendez@ucaldas.edu.co
}

\begin{abstract}
How to cite: Méndez Sastoque, M. J. (2022). Towards a living agriculture: extension of the notion of agriculture among rural extension agents based on a comprehensive approach to indigenous knowledge in Caldas, Colombia. Revista de Economia e Sociologia Rural, 60(3), e230388. https://doi.org/10.1590/1806-9479.2021.230388
\end{abstract}

\begin{abstract}
Agriculture as a business remains the dominant notion among agronomists that work as rural extension agents. Following this vision, their main contribution is to transfer the technical-scientific knowledge for manipulating natural environments to maximize the yield of the communities of cultivated plants. However, it is considered that contrasting one's ideas with those of others -in this case native communities- allows us to recognize, reflexively, the preconceptions themselves. In this framework, the objective of the investigation was to determine how the dominant point of view among agronomists educated within the technical-scientific paradigm changes upon comprehensive interaction with the traditional knowledge. Results derive from analyzing the interviews of rural extension agents who offer their services to native communities in Caldas, Colombia. From the analyses, it can be concluded that, nowadays, agronomists more easily understand that in the local context, agriculture, rather than a business, is a life-producing activity; that elements of nature are subjects that interact and coexist around the reproduction of life rather than objects to manipulate and appropriate; that, in practice, the scientific knowledge adopted is blended with traditional and mystic knowledge, thereby creating a multicultural conservationist practice.
\end{abstract}

Keywords: rural extension, traditional knowledge, scientific knowledge, intercultural dialog, caring agriculture.

\begin{abstract}
Resumo: A agricultura vista como um agronegócio continua a ser a noção dominante entre os agrônomos que trabalham como extensionistas rurais. Guiados por essa visão, transferir conhecimentos técnico-científicos para manipular o ambiente natural, a fim de maximizar o desempenho das comunidades de plantas cultivadas, é sua principal contribuição. No entanto, supõe-se que confrontar dita visão com a de outros sujeitos, neste caso membros de comunidades indígena-camponesas, Ihes permite questionar, reflexivamente, os próprios preconceitos. Nesse contexto, a pesquisa visou indagar como essa visão dominante entre os agrônomos formados no paradigma técnico-científico muda ao entrar compreensivamente em contato com o conhecimento tradicional. Os resultados derivam da análise de entrevistas com extensionistas rurais que prestam serviços a comunidades indígenas no departamento de Caldas, Colômbia. Conclui-se que os agrônomos consultados com mais facilidade hoje entendem que, no contexto local, a agricultura, mais do que um negócio, é uma atividade produtora de vida. Que os elementos da natureza, em vez de objetos manipuláveis e apropriáveis, são sujeitos com os quais se interage e coexistem em torno da reprodução da vida. Que, na prática tradicional, o conhecimento científico adotado é amalgamado com o conhecimento tradicional e místico-sagrado, originando práticas interculturais de conservação.
\end{abstract}

Palavras-chave: extensão rural, conhecimento tradicional, conhecimento científico, diálogo intercultural, agricultura do cuidado. 


\section{Introduction}

For individuals who are daily in contact with rural communities, primarily peasants, including members of native communities, recognizing the existence of traditional knowledge that guides its productive and agricultural practices is becoming increasingly evident. Nevertheless, its visibility has implied moving forward to its acceptance, starting from a gradual transformation of the dominant visions regarding this knowledge.

Following this, adapting the explanation by Argueta (1999), several coexisting trends at present illustrate the route taken concerning traditional agricultural knowledge: a) first, when this knowledge is not even perceived and even less recognized but once perceived, is considered primitive and obsolete; b) second, a tendency wherein upon recognizing the knowledge, considers that this knowledge should be overtaken or eliminated, as it is an obstacle to the modernization of agricultural production; c) third, a trend that is radically opposite to the previous one wherein when recognized, the knowledge is idealized and resolutely protected from any contamination from the modern agronomic knowledge and; d) fourth, a trend that values the contribution of traditional knowledge to knowledge as a whole, via exchange and horizontal dialog with others, including scientific knowledge.

Based on own experience, the initial assumption is that in places providing professional training in agriculture and livestock sciences, such as agronomy schools and universities, the second trend previously outlined is prevalent. Accordingly, teaching and learning to use scientific knowledge for manipulating the environment associated with a cultivated plant community to optimize the production of food and materials useful for humans is the main professional and formative purpose (Villalobos et al., 2009). This tendency is prone to a dismissal of the implementation of another type of knowledge regarding crop systems management and considers the scientific perspective from modern science as the only possible option (Cruz et al., 2015).

Considering these circumstances, professionals educated in those contexts, particularly agronomists who work as rural extension agents, barely discover the existence of other agronomic knowledge when they interact in the field with traditional producers and with their ways of conceiving agriculture. In such meetings, during which at first the asymmetry of power between the different knowledge and wisdom is revealed, the first reaction from the rural extension agents tends to be the depreciation of traditional knowledge. Discrediting and regarding it as archaic, overdue, or obsolete -expressions that demonstrate irritation and disdain for the traditional knowledge (Toledo, 2005)- reveals the power imbalance that situates scientific knowledge as superior and modern.

In this context, as Souza (2009) has mentioned, scientific rationality aims to be established as "the demarcation criteria between what is valid as knowledge and what is not" p. 208. Along these lines, the traditional knowledge of peasants and natives, when considered insignificant, speculative, and illogical, is predestined to be replaced by the one derived from occidental science (Rodríguez-Moreno, 2014). In practice, according to an approach of conventional rural extension, the role of rural extension agents should be, in sum, a contribution to modernize both agriculture and farmers under dominant scrutiny that qualifies them as pre-modern, traditional, and sometimes ignorant, which do not recognize the validity of its knowledge and experiences. Under this logic, the conventional path would include introducing new scientific and technical knowledge in rural areas, changing their traditional ways of thinking and performing, aiming to generate productive changes, and improving the quality of farmers' life and their families (Pavón, 2014).

However, in contrast, it coexists with an alternative perspective that, in sum, promulgates the following: 
* That, although we are different, with some actors being graduated in agricultural sciences, some being educated at schools, and others directly in natural environments and family farms, such difference disappears when we perceive each other as experts trained in different contexts, owners of wisdom (in permanent construction) to be shared and complemented with the others.

* That the cognitive heritage useful to solve issues and to interpret concrete facts within a particular context (including the productive and agricultural ones) is integrated by multiple data of diverse origins and bases. This group includes local traditional and scientific knowledge, with equal validity and hierarchical position.

This is regarding a view consistent with the fourth trend explained by Argueta (1999), focused on the exchange and dialog of knowledge. Considering the description by Delgado \& Rist (2016), the challenge should be to determine an approach to foster dialog and cooperation between various social actors, with different ways of knowledge, instead of imposing a unique vision of the world based on a hegemonic speech that silences any other. As well as to understand that, despite their differences, scientific and traditional agricultural knowledge "are not exclusive or irreconcilable; they just belong to typical routines from different social environments" (Alemán, 2016, p. 5).

In this context of openness to dialog and life areas intertwining, it can be added that, based on social interaction, the others' thinking and performance, their visions of the world, and their truths do not appear odd to me. Empirically, the gradual "face-to-face" encounter between extension agents and traditional farmers allows the tension between the parties to dissolve. Understanding the world of the other, the reason that guides and renders sense to their actions, their relationship with nature, their cosmogony, and worldviews, without judgment, is the first step toward intercultural dialog. Type of dialogue based on the multidirectional openness to the thought and knowledge of the other, in conditions of equality, dignity, and legitimacy, which questions the patterns of power and encourages the creation of new perspectives to read and understand critically the world, making visible and forging different ways of acting, thinking, living and knowing, dissimilar from those inscribed in modern-western reason (Walsh, 2009). Within this context, it is accepted that for agronomists serving natives and peasants, daily "face-to-face" meetings and performing work together are sources of multiple learning. These lessons derived from the intercultural dialogue are investigated in the present study, whose aim is to answer the following question: For agronomists educated within the scientific-technical paradigm, after being compressively close to traditional and native knowledge, how is your way of meaning or conceiving of agriculture widened or modified?

To answer this question based on empirical evidence, the objective was to determine how the notion of agriculture that predominates among rural extensionists who provide services to indigenous communities in the department of Caldas, Colombia, changes after their experiential and comprehensive interaction with traditional indigenous knowledge.

\section{The theoretical framework: promoting the integration of knowledge for a more sustainable agriculture}

As a starting point, we assume that the agricultural knowledge available today is an amalgam of multiple knowledge. In specific social contexts, such as the one studied here, traditional and scientific knowledge, being part of this set, are simultaneously used by multiple actors in agricultural activity (Sumane et al., 2018). In these spaces, bearers of one or another type 
of knowledge interact with each other, permeating the knowledge of the other, a situation that, at some point, can become conflictive, given the disparity of powers between one and another knowledge (Kloppenburg, 1991; Pawluk et al., 1992). At first, as already mentioned, disqualifying the knowledge of the other, assuming it as archaic or premodern, is a source of conflict based on the apparent superiority of scientific knowledge (Agrawal, 1995; Argueta, 1999; Rodríguez-Moreno, 2014). However, approaching the knowledge of the other, which is realized in the middle of social interaction, also allows us dissipating these tensions.

Sharing the same space, having a "here and now" in common, supposes the overlap of intersubjectivities (Berger \& Luckmann, 1979). In this case, while the exchange between the parties intensifies, in the same way, that the differences become more visible, their perspectives on the world and their ways of conceiving agriculture also become more compressible. In this context, how the other perceives the world, even if it is not shared or fully understood, is no longer strange to the counterpart. It is a meeting between different actors that, over time, allows us to advance mutual knowledge and deconstruct the stereotypes used to identify the other (Berger \& Luckmann, 1979; Brückner, 2006). As a second step, recognizing how the knowledge of the other can complement one's knowledge gives rise to the synergistic dialogue of knowledge. Under this logic, adding knowledge would result in a more comprehensive intercultural practice that would incorporate elements of different origins and respond to several interests at once, including those that are common.

In this addition of knowledge, the knowledge of native farmers, based on their practical experience and in-depth knowledge of local agroecological conditions, adds to the knowledge acquired by extension agents in universities and scientific training centers. The technological knowledge of extension agents, initially assumed as universal, meets the native knowledge much more local and adapted to specific local and cultural conditions (Delgado \& Rist, 2016). The knowledge of extension agents, aimed at increasing productivity and income, adds to the indigenous knowledge applied to answer multiple items (Briggs \& Moyo, 2012): income generation, food security, nature conservation, sustainability of the biological diversity, maintenance of ancestral culture, strengthen the social ties. The knowledge of extension agents based on scientific calculation is mixed with indigenous knowledge tied to their myths and worldviews (Sanabría \& Argueta, 2015), for example.

In this perspective, this traditional knowledge understood as a set of knowledge, practices, values, and beliefs conceived from the adaptation to the local environment over time, transmitted from generation to generation (Panizo \& Perdomo, 2017), despite its persistence, it is also open to the new. Opening a little less seen when the knowledge that opens to the other or different is the scientific-academic knowledge.

Coinciding with Agrawal (1995), it is a native knowledge open to innovations, which selectively includes elements from scientific agricultural knowledge. Action empirically based on the "face-to-face" encounter between social actors with knowledge originated from different logics, but willing to learn from each other: natives learning from extension agents without giving up their knowledge. This is an attitude that is also expected in extension agents, whose knowledge must be opened to traditional knowledge. We assume that in their condition of holders of scientific knowledge, perceiving traditional knowledge as complementary to their own, and not as the opposite, would allow extension agents to expand their resource base to meet the objectives of agricultural and rural development (Pawluk et al., 1992; Roland et al., 2018). In this case, conceiving knowledge as useful, above its differences of origin, would be the key to its articulation. 
During the dialogue and social interaction, observation, and experimentation, the usefulness of knowledge is recognized by the parties. In local agricultural production processes, farmers incorporate the multiple types of knowledge to which they have access, which they consider relevant (Agrawal, 1995). Likewise, extension agents integrate the knowledge learned from farmers into their technological heritage, which they consider effective. As a result of this exchange, traditional knowledge can be technically validated and scientific knowledge empirically corroborated as useful (Kaup, 2008). It is a multidirectional process aimed at integrating knowledge based on common objectives, where scientific and traditional knowledge complement and improve each other (De Walt, 1994; Clark \& Murdoch, 1997).

In this dynamic, the multiple actors, including scientists, extension agents, indigenous and peasants, must be recognized, on equal terms, as co-authors and co-protagonists in the production of useful knowledge (Sumane et al., 2018). Knowledge today is mainly aimed at forging more sustainable agriculture, for which integrating multiple knowledge is necessary (Delgado \& Rist, 2016; Lehébel-Péron et al., 2016).

As recognized by multiple authors, traditional knowledge of farmers today is increasingly seen as a way to design sustainable agricultural systems (Molnar et al. 1992; Raymond et al., 2010; Altieri \& Nicholls, 2017; Casey \& Thomas, 2018; Wang et al., 2019). In this direction, the indigenous and peasant communities of Latin America and the world today are bearers of an invaluable culture capable to support more harmonious agriculture (Swartley, 2018; Barrasa \& Reyes, 2011). In this case, if producing while conserving natural resources has been an ancient purpose of these communities, how not learn from it?

Different studies argue that moving towards sustainable agriculture has been more effective when actors with different knowledge interact and negotiate new agricultural practices (Tisenkopfs et al., 2015; Cruz-León et al., 2015; Moschitz et al., 2015). In this way, as several investigations show, designing alternative agricultural systems that integrate internal experimentation and creativity with the contributions of external expertise has allowed us to make better decisions about the management of natural and productive resources (Nyong et al., 2007; Mapfumo et al., 2016; Granderson, 2017). In these cases, having agroproductive systems much more adapted to local conditions and planned in conjunction with the local population has been the main result.

However, in certain contexts, extension agents and other agricultural professionals continue to think agriculture conventionally. For them, maintaining the economic sustainability of the agricultural business, as already mentioned, is their main objective (Méndez, 2008). Focused on its economic dimension, promoting the adoption of scientific-academic knowledge to increase crop productivity is the primary purpose. This objective becomes relativized through dialogue and interaction with indigenous communities and their traditional knowledge. Approaching other ways of conceiving agriculture, from the perspective of other social groups that practice this activity under other parameters, allows their initial notions to change and incorporate new elements. Along these lines, this study examines how extension agents trained within the technical-scientific and economic paradigms change their notion of agriculture by exposing themselves, reflexively, to traditional indigenous-peasant knowledge during their daily professional practice.

\section{Methodology}

To answer the abovementioned question, the agronomists' experiences and perspectives related to the service of public extension of seven city halls of the department of Caldas, 
Colombia, were questioned. All the participants are professionals appointed to the Municipal Agricultural Technical Assistance Unit(UMATA) of the city halls of Anserma, Belalcazar, Filadelfia, Riosucio, San José, Supía, and Viterbo. Jurisdictions with the presence of the native population belonging to the Embera-Chamí (Men from the Mountain Range) ethnic group, to whom the rural extension agents of the UMATA provide technical and agricultural assistance services.

They are indigenous individuals whose economic basis is the agricultural production for self-consumption: banana, yucca, corn, bean, panela sugarcane, cold climate fruit trees, and medicinal plants in individual or collective vegetable gardens. This work is supplemented with the small-scale commercial production of coffee, cocoa, blackberry, and passion fruit, which is distributed in local markets and neighboring populated areas, in addition to their sale to intermediaries who trade them in other markets. Considering its cosmogony, both production types are performed following traditional practices, such as rituals for Mother Earth, the blessing of seeds, ceremonies of nature harmonization, and agricultural lunar calendar observance. According to the representatives of the Native Regional Council of Caldas (Consejo Regional Indígena de Caldas, 2004), production methods are now affected by "the loss of a harmonious relationship with Mother Earth, permeated by Kajuma [western] concepts of exploiting and trading," according to which land is an exploitable object that "can be polluted with poisons, among others." Given this situation, communities have instructed the governmental entities, including the UMATA, to "examine and adjust any practice that may endanger both biodiversity and traditional wisdom existing in their territories", instruction registered in the Plan for Protection of the Town of Embera of Caldas (Consejo Regional Indígena de Caldas, 2004) currently in force.

The main selection criterion for the interview was that the agronomists must be employed under this condition. The main selection criterion for the interview was that the agronomists must be employed under this condition. A total of 23 semi-structured interviews were conducted between June and December of 2018 with all agronomists currently associated with the UMATA of the city halls participating in the study. Taking the question of investigation as a reference, interviews included the following topics: a) contrast between their knowledge and the traditional agricultural knowledge, b) learning about the implementation and validity of traditional agricultural knowledge, and c) considerations derived from the exchange of knowledge related to agricultural production. Each meeting was a moment of dialog and deliberation on the practice of rural extension rather than a simple questionnaire, with conversations focused on the experiences and personal reflections of the rural extension agents in terms of the abovementioned topics. Each interview lasted for approximately $50 \mathrm{~min}$. The objectives and scope of the investigation, the type of participation requested, and the possible uses of the results were previously communicated to the interviewees, who gave their consent to use the information generated (Meo \& Navarro, 2009).

Consistent with Attride (2001), once the interviews were transcribed, the steps for analysis of the information included the following: a) the repetitive reading of texts (transcriptions), b) the detection of emerging topics and similarity-based classification, c) the definition of topic categories for analysis, and d) the analysis and interpretation of results. Functionally, once the analytical categories were established, texts resulting from the interviews were divided into segments and classified according to each category, registering the name of the rural extension agent to whom the testimony belongs for each segment.

\section{Results and Discussion}


The analysis of texts allowed us to identify three main topic categories concerning the widen or modification of the way of meaning agriculture: a) agriculture as a life-reproductive activity, beyond a simple economic activity, b) agriculture as an intercultural practice integrator of multiple knowledge and c) traditional agriculture as the foundation of a caring agriculture alternative to industrial farming. Each of them is then developed, accompanied by fragments of interviews translated from Spanish to English.

\title{
Going beyond economic productivity: agriculture as a life-reproductive activity
}

Initially, the main mission for most of the extension agents who were part of the study was to increase the technical level of agricultural production. With this goal, the practical objective of technification was to increase crop productivity and consequently the farmers' monetary income. Accordingly, in their own words, their work focused on "helping make the agricultural business more profitable," "making producers increase their income," and "contributing to the improvement of rural farmers' living conditions" via the use of modern technology for their crops and to increase their income. In this context, having farmers believing their rural properties as "companies" and considering themselves as "businessmen," rather than rural farmers or peasants, went together with the use of technology in their operations.

However, this marketable vision of agriculture that virtually transforms it into commercial activity, which prevails at investigation and agricultural training centers as well as in government entities related to rural and agricultural development (Cruz et al., 2015), was gradually mitigating to be contrasted with other coexisting proposals:

\begin{abstract}
"I recently joined the UMATA, as I intended to share knowledge learned at university with small farmers. I could contribute to the areas of land management, pest and disease control, fertilization, weed control, and integrated crop management, among others. The aim was for these farmers to incorporate new knowledge, improve their production methods, and increase both their productivity and income. However, gradually and after several attempts, I discovered that we were not as connected as I believed. I realized that we had different perspectives and ways of working until I began to understand their way of thinking, which started to change mine. For them [native and peasant], agriculture was more than a business; it was their way of living, their way of creating life. I was able to realize that once I started listening to them and getting to know them better.
\end{abstract}

For them, everything they produce, such as food, is more than just goods. This does not mean that they do not sell the surplus in the market, but they perceive them as a source of life. The land, which they consider their mother, is the source of life. It produces what they require to live, namely, foods, which at the same time have life inside and reproduce that life. A life that is transmitted to those who consume them becomes a reason to care for the land and caring for the life. This vision was new for me, as I have never been associated with such concepts. I believed agriculture was a productive activity, a resource-producing task, which produced goods that supply the markets and are simply food and raw materials that, via a monetary exchange, are purchased by consumers.

Today, my vision is definitively different. When I work with them, when I provide them with technical assistance, my purpose also consists of caring for the life and producing it, which is an idea that I have learned from them" (Interview No. 3).

Analytically, the previous testimony allows us to demonstrate how traditional knowledge permeates the perspective of the extension agents regarding the meaning of agriculture. As interviewees described, for the native-rural communities that they are locally related to, crop areas and agriculture itself have a special significance and meaning. In contrast, according to agronomists, agriculture tends to be an economic activity with commercial and profitable aims, whereas native farmers consider it a sacred activity that reproduces life. Agronomists believe 
that land is the material substratum for agricultural production, whereas native communities affirm that Mother Earth generates the life of all beings (Sanabría \& Argueta, 2015). She is venerated as the mother who provides the food, products, and energy required for reproduction purposes (Chilón, 2018). In this context, wild and cultivated plants as well as the Mother Earth supporting them, rather than being exploited by humans, must be respected and cared for as life creators.

Considering the above, in contrast to the conventional vision, some of them today argue that the agronomists' work should go beyond incorporating scientific knowledge to maximize crop efficiency and productivity:

\begin{abstract}
"Throughout my career, I have learned that technical knowledge can also be used to protect and preserve. Producing as well as preserving life and the land, which is a source of life, is achievable by us. Producing healthy food, which is the source of life and vital energy, for consumption by individuals and animals is a professional responsibility. Today, by working close to native communities, I am more aware of the fact that the final objective is not to simply improve production at all costs, because not much is gained from land overexploitation and turning it into an inert being. Currently, I am more aware of the need for producing while protecting, of the need of protecting productive resources as well as all life itself, i.e., the lives of the soil, water, and plants" (Interview No. 7).
\end{abstract}

In this case, because of dialog and interaction, extension agents perceived that from the rural-native perspective, increasing the production per unit area is not the single or main concern. In practice, the production of the food required to support families to generate surplus for trade is added to the intent of taking care of the land in its condition of living being and life creator. The exchange of knowledge, preservation of land fertility and stability, rational use and preservation of water, eco-friendly production, and the preservation of the existing diversity, among other actions, would be a part of the common objectives. In this regard, going beyond the common profitable purposes, considering the effects of agronomical practices on soil, water, welfare, and animal and human health, as well as other elements, would be the new guiding perspective (Villalobos et al., 2009).

However, it is crucial to consider that this conservationist perspective, which is apparently close to the proposals of one of the definitions of sustainable agriculture-the prolongation of the function of agricultural systems, starting with the preservation of natural resources, keeping exploitations economically viable (Villalobos et al., 2009)—goes beyond this functional and mechanical vision. In this case, the vital and organic vision of the rural-native population that is significantly different from the conventional mechanistic, scientific agronomical point of view (Hoefle, 2009) is the one that permeates rural extension agents' vision. From this perspective, elements, such as water and soil, which are conventionally perceived as objects essentially used for agricultural production (functional and mechanistic vision), are more than simple productive resources that are conceived as vital beings integrated into a universal life, whose protection obeys to the need of protecting life itself, strengthen the understanding and cohabitation between complementary and coexisting beings:

\footnotetext{
"What was difficult for me to understand at the beginning is how communities treat soil and water. Farmers consider that they are alive; that they are beings with whom they cohabitate; and that they get angry when mistreated and are friendly or amenable when they are well treated. I am trying to assimilate this idea; it makes more sense to me over time. For example, one case that concerns the soil is that it responds according to the treatment it receives. If we overexploit it or use aggressive technologies, it gets sick or damaged, thus becoming less fertile. If we contribute to its acidification or do not rotate crops to let the soil rest, he gets sick. Similarly, if we do take care of it by hydrating and oxygenating it or by feeding it with more organic matter, it revives and becomes fortified, sharing its virtues with us" (Interview No. 11).
} 
In this testimony, as in other similar cases, when interviewees personify soil, referring to it as "he or she," the reflective wisdom exchange and partial incorporation of the other individuals' knowledge are observed. Attributing life to soil and not considering it an inanimate or immaterial entity leads to a kind of relationship that is more associated with fraternal and supporting care than just conservation with functional objectives, as reflexively learned by extension agents. They recognized that according to rural-native thinking, if there is inadequate input, with no listening, understanding, or love, Mother Earth withers (Rodríguez-Moreno, 2014). Like other living beings, if they do not receive sufficient care, land can get tired, sick, angry, thirsty, or stressed. However, they are also aware that the damages caused can be rehabilitated or invigorated, depending on the affection, gestures of reconciliation, and good care received (Barrera-Bassols et al., 2009).

In a considerate manner, this context of learning and practice leads to the approach known as "caring agriculture," based on the practice of values such as coexistence, respect, reciprocity, good treatment, and dialog between all beings that are part of an agricultural living community.

As Boff (2005) explains, it would be a way of making agriculture perceive nature and all its elements as subjects with which it can interact and coexist and as part of an articulated whole rather than as an appropriate and manageable object for meeting different needs and human desires, albeit without focusing away from the purpose of land cultivation. In practice, to feel appreciation, concern, gratitude, and respect for the land, water, wild and cultivated plants, air, and all organisms that are a part of the (agro)ecosystems would be the basis for establishing a more harmonious and horizontal relationship. Given this logic, when its existence is important to me (as a farmer, farmer, agronomist, extension agent or agricultural development planner, member of the agroecosystem and not as someone who dominates and uses others), dedicate time, act in for their welfare, not attacking them, and developing a sense of responsibility in cultivating the soil and producing food and other goods would be the basis of caring agriculture. This notion incorporates some elements of contemporary reflexivity around nature-society relations (attitude of respect towards nature and all forms of life, need to halt environmental degradation, awareness of the interdependence between nature, human life, and society), today seen in the light of current environmental problems.

In this context of (bio)coexistence and care, according to the analysis, another learning derived from interaction with rural communities was the application of the diversity principle:

\begin{abstract}
"At university, during my educational progress as an agronomist, I have learned to perceive isolated and separated things. Each crop, such as potatoes, coffee, and different vegetables and fruits, is studied separately. Every agricultural system is a mono-crop, under the assumption that farmers tend to specialize in one or just a few species. However, when I started visiting rural farms, I realized that there is a bit of everything in a small area. Within their properties, during coffee cultivation, it is easy to find several different plants for medicinal use, different fruit trees, decorative plants, and other plants used for religious rituals in the same region. In such regions, we find combined crops, with the ways of production being different from a conventional crop and being rarely studied at universities" (Interview No. 9).
\end{abstract}

As Toledo (2005) mentions, unlike agroindustrial systems, traditional agricultural systems, with their logic focusing on the specialization (mono-crop) and simplification of the biological, ecological, and genetic complexity, are established on the diversity principle. In this case, acknowledging and accepting this logic, having to unlearn part of what has been learned about the agricultural system management, has been one of the results of interaction and knowledge exchange. Conventionally, knowing and teaching the ways to reduce energy losses over trophic strings in agricultural ecosystems thereby attempting to eliminate the major part of unwanted 
energy transfers via other plants or organisms that compete with the crop (Villalobos et al. 2009), has been an essential part of learning and has incorporated into practice by agronomists in the field. This contrasts coexistence between species promulgated by traditional knowledge, which attempts to emulate the natural order to a certain extent. As Núñez (2004) states, the peasants' knowledge associated with the breeding and protection of biodiversity in their agrosystems look forward to reproducing, cultivating, and preserving various fauna and flora species related to their daily life, rather than reducing it. By coexisting with this species, their care ensures availability for multiple purposes: food, ornaments, health, harmonization, construction, and use in ceremonies and rituals, which are uses that are beyond commercial purposes.

In light of this, adapting their knowledge to other ways of carrying out and perceiving agriculture, nourishing themselves with the traditional knowledge of the native communities with which it is related, has been one of the tasks undertaken by the agronomists interviewed. In this case, considering what La Vía Campesina (2013) showed, preserving the coexistence of certain types of agriculture with trees, forests, mountains, rivers, and lakes would be the main challenge for them, in contrast to the agricultural corporate model without farmers and with monocultures and green deserts. Such a challenge implies showing greater respect for life, protected by a broader vision of what is considered a living being, which could lead to an agricultural practice based on the preservation of life

\section{Toward horizontal and respectful conjunction of knowledge and agricultural practices: agriculture as an intercultural practice}

For agronomists and other professionals in agricultural sciences, referring to data technically generated in meteorological stations or checking climate forecasts provided by agricultural advisory services is usually a part of their routine. Planning activities, such as sowing, fertilization, and harvest seasons, taking preventive measures given adverse factors (drought, ground frost, torrential rains, and others), and determining areas suitable for each crop require such information. However, once in the field, these professionals can more closely observant that these are not the only sources of information used. For this case study, the indigenous population and peasants interact with resorted to their forecasting systems:

"While working with them, I had to adapt to their way of planning crops. For them, phenomena such as the phases of the moon are crucial and decisive. For example, to ensure optimal health of plants and achieve the expected results, seeds are selected during the waning phase and germination tests are performed thereafter, which is the process we follow from UMATA. However, according to their knowledge, to enable coffee plants to properly adapt to the soil, the plants must be transplanted during a full moon. This practice is strictly followed, in addition to the technical recommendation of incorporating mycorrhizas during the sowing process. The latter must be performed during the waning phase to ensure that the corn grows strong and to prevent it from being knocked down by the wind. This is the wisdom that they have received from previous generations and currently use to plan activities, possibly combined with technical knowledge. I have learned to respect this knowledge, which is difficult to explain, but is implemented and is successful most of the time" (Interview No. 15).

This involves a planning and prevention system against adverse biological and climatic phenomena, based on the recognition and interpretation of natural indicators. The astronomical positions, behavior of certain animals, germination or flowering of any plant in the cultivation zone, and stopover area of migratory birds, among others, are part of these natural signs locally considered by the natives and peasants when planning their farming practices. Decisions 
regarding what, how, and when as well as the quantity and location to sow are made using these natural signs that are indicators that emerged from the millenary experience of observation and validation of results. Although they may lack scientific accuracy and the instruments or technological methods currently available, they use their five senses trained over time (Van Kessel \& Enríquez, 2002). Nevertheless, as shown in the previous testimony, this is regarding a traditional planning system that is open to new non-contradictory incorporations that respect its essence, rather than a secretive or closed system.

Without relinquishing to self-knowledge, but estimating the validity of the other's knowledge, both parties have contributed to the local agronomic knowledge. In this case, the planning system, based on the recognition and interpretation of natural indicators, has satisfactorily been combined with another planning and prevention system based on technical-scientific knowledge (seed germination, vigor, and physiological quality tests, and water balance evaluation, as mentioned by the interviewees). This teaches extension agents to recognize the existence of other agricultural production guiding beliefs, knowledge, and values as well as to increase their awareness of the possibility of conjunction. In this instance, recognizing, accepting, and combining such knowledge has been the result of horizontal interaction and the dialog of wisdom.

In parallel, extension agents have learned regarding the simultaneous existence and applicability of another type of knowledge equally essential for agricultural activity. This is regarding the knowledge that connects the traditional communities and the sacred and supernatural world.

"I have learned to respect the rituals and sacred ceremonies. For a substantial proportion of the peasants from the municipalities, praying to God and the spirits for a good harvest, praying to San Isidro during times of heavy rainfall, starting sowing with a ceremony to be in harmony with nature and Mother Earth, and being assisted by a traditional doctor or a community senior are common practices that are highly valued. From my perspective, these are beliefs and rituals to be respected, rituals that make them be at peace with God and nature and help them rely on divine intervention for managing everything. Actions, such as asking Mother Earth for permission to plow the land, are beautiful and spiritual to me, as cultivation largely depends on it as well as on the water and the sun. Therefore, I have learned to respect and combine things, as I believe this type of divine help is never too much. In my opinion, good technical knowledge and great agricultural practices may easily be supplemented by the spiritual dimension, as I usually tell my colleagues, agricultural engineers, and veterinarians, who still consider these rituals as fraud or superstition"(Interview No. 1).

In this case, along with the recognition of the existence of other types of knowledge guiding agricultural production processes, mystical or sacred wisdom emerges. As evidenced in the testimony above, social groups such as nature-dependent farmers involved in this study, who are directly exposed to environmental conditions as a possible mediator between the human, the unknown, and the natural environment, have maintained the need to come into contact and engage in a dialog with the supernatural world (Núñez, 2004; Rodríguez-Moreno, 2014; Chilón, 2018). Practices, such as those mentioned by the interviewees -i) direct communication with the spirits of nature through meditation or rituals and to be in harmony with it; ii) cleansing and purifying lands for seed sowing to protect them from bad energy and prevent the occurrence of climatic diseases or illnesses; and iii) praying and giving offerings both to Catholic saints and beings from the spiritual world of the Embera individuals in pursuit of protection and support to obtain a good yield, among others- are practices locally integrated to the agricultural activities, occasionally consistent with that reported for the other cases (Rosset, 2015; Sánchez, 2017) and are widely recognized, respected, and accepted by extension agents today. 
In a reflective manner, the extension agents' learning has involved understanding that local agricultural knowledge, whether it integrates logical- and scientific research-derived knowledge, is not isolated from the mystical-sacred order in which magic, religiosity, and myth are the key elements. Thus, for local natives and peasants, those elements are a part of a full and multidimensional vision of the world (Bermúdez et al., 2005) and of a polytheist and vitalist worldview that does not conceive men and deities as radically separate from nature. As shown below, these entities converse and influence each other:

"Don Marcos, a peasant who resides in the upper part of the district, repeatedly assures me that when his family and the entire town devotedly celebrate St. Anthony's feast day, bean and corn crops are at their best. In his opinion, celebrating with a big party, crowding in the church for the Mass, decorating the church with flowers, being involved in the celebration with much faith, and sharing food and drinks with the others makes the saint feel loved, remembered, and cared for by them and he protects their animals and crops from adverse weather or disease. The same activities are performed for Mother Earth when they offer water, traditional beverages, and food during a ritual. Thus, they thank her for being a good mother and for providing them and their children with food and resources to survive. Moreover, he asserts that when rituals are not performed with sufficient faith and devotion, Mother Earth is disheartened, which results in rainfall disappearing and fertilizers applied to show no effect on plants, thereby influencing the crop growth" (Interview No. 13).

In an interpretative way, resorting to sacred intervention via rituals and harmonization activities, as suggested by the previous testimony, along with others, is a method to deal with the uncertainty associated with agricultural production, in addition to other more physical unexpected elements. As we, the farmers and agronomists, know that depending on highly variable and unpredictable climatic events and biological factors renders agricultural production a risky activity. The fear of suffering water excess or deficit, low or high luminosity, changing relative humidity, and oscillating temperatures, among other factors that are not always predictable or controllable, turns to resort to divine intervention into a purposeful act in the context of a community that believes in sacredness. An action more freely expressed by peasant farmers, following a natural, syncretic, and mixed-blood Andean worldview (Toledo et al. 2003), is somewhat concealed among the agronomists' community because they clash with their scientific education.

In this regard, according to Chilón (2018), turning to the divine forces boosts confidence in native and peasant farmers to proceed with the risky agricultural activity by mitigating, even in part, their fear of the uncontrollable or unmanageable. Without this spiritual means, facing the risk and continuous uncertainty characteristic of the farming activity would be extremely difficult. Every agronomist (and any other professional) diligently working in these communities should be aware of these circumstances. This consideration gives meaning to the following questions (Alarcón, 2016): to what extent do farming rituals stop being a symbolic act to become a practical act? Why keep these rituals within the context of the magic or symbolic and not attach pragmatic and objective value within the farming production framework?

"Although at first, combining technique and religion was a challenge for me, I have accepted and
convinced myself that both go together here. Even if a producer is convinced of the convenience
of performing a soil study to define the fertilization plan, he will not stop praying to God for that
to be fruitful. Although he succeeds in preparing the soil, he will not stop asking Mother Earth to
embrace the seeds that will germinate in it. Among them, the so-called spiritual practices are as
needed as cultural practices. That is to say, the need to pray is like the need to fertilize, irrigate, 
and weed. These are comprehensive practices that are a part of the local agriculture-showing respect as well as faith and hope" (Interview No. 17).

As stated in the above testimony, each ceremony or ritual performed would take the form of the practice associated with regular and full crop management. Such features are based on the inseparability of the various agricultural practices, which become one, thereby amalgamating the material and symbolic; the natural, human, and supernatural; and the matter and spirit of things. This combination, in terms of dialog and exchange of knowledge, includes the merger between agronomic-scientific knowledge, traditional ecological knowledge, and the spiritualexperiential knowledge, a cognitive heritage guiding agricultural production decision-making.

In other words, such learning would entail recognizing the existent indivisibility among the native and peasant worldview and practice (Van Kessel \& Enríquez, 2002), a global view or conception that is currently more widely recognized and valued by rural extension agents who act locally, although little regarded by those who think and plan agricultural and rural development externally and distantly, as described below.

\title{
Traditional culture as the foundation of caring agriculture
}

Although the contribution to progress toward environmentally sustainable agriculture is one of the current goals of the agricultural training and research centers, which is also the purpose of extension agencies for the agricultural and rural development in Colombia (Instituto Colombiano Agropecuario, 2009), as shown below, this has poorly visualized and integrated the practices and knowledge applied by traditional communities:

\begin{abstract}
"In the municipality, as UMATA extension agents, we are both responsible for fostering the farmers' implementation of Good Agricultural Practices in each existent crop. Following the ICA (Colombian Agricultural Institute), our mission is to ensure that peasants adopt environmentally appropriate and eco-friendly practices that avoid water pollution, ozone depletion, soil acidification, and erosion and contamination caused by agrochemical waste. These are technical measures that are environmentally appropriate, which most of the time have already been followed by local farmers, although in their way. For them, caring for the land, water, and air, their life sources, asking for Mother Earth's permission to carefully plow it, resting the land to avoid wearing it out, cultivating multiple species, and reproducing and exchanging seeds to preserve life are practices that are already implemented. However, because these are not techniques or practices coming from a research institute, they tend to not be well valued. On the day / presented my management report, for example, in a certain community, farmers performed a ritual to be in harmony with nature, offering food and drink to the land to strengthen it after harvest. These practices cannot be understood by those who are not familiar with their culture" (Interview No. 2).
\end{abstract}

In this case, although the practices encouraged by extension agents and those autonomously performed by the communities share a common goal (the conservation of nature and its assets), the imbalance between technically validated practices and those supposedly based on pre-modern beliefs or superstitions stand out. In practice, as learning, the extension agents embedded in the local dynamics have experienced the existence of a global agricultural model that, in its homogenization efforts, minimally considers the situatedness of knowledge, seeking to replace local agricultural practices with standardized and foreign actions and measures, thereby demonstrating global-local conflicts and disparities (Kottak, 1999; Gómez \& Turbay, 2016).

In this context, "good agriculture," regardless of the place where it occurs, would have to answer to the quality standards currently agreed upon by the expert community (including a large proportion of the academic community), mostly in response to the market demands 
(innocuous food produced under low-risk chemical, microbiological, and environmental contamination conditions) and the technical rules established by external certification entities. This is a rationality that by prioritizing the material, technical and tangible parameters, invisible or relegates to the background the integrative view of traditional communities, the relationship of the farmer with spiritual life, and, in general, the rules, beliefs, and foundational values of their conservationist-vitalist practices. A traditional vision that goes beyond material and commercial interests.

In this scenario, when evaluating their professional approach critically and reflexively, agronomists learn to act considering the characteristics of the local socio-cultural context, making an effort to recognize and understand the culture and worldview of local communities, to act accordingly and contribute to reducing power imbalances:

\begin{abstract}
"I have clashed with extension agents from the Extension Service of the Coffee Growers Committee in the municipality. They consider that, in line with the trade union policies for coffee farmers, it is almost mandatory to provide priority to coffee mono-crops over other crops, in addition to sowing the improved varieties recommended by them and following the plan proposed for technical crop management. However, I believe that this is not the proper method for this area. If they understood the logic of the communities, they would know that the communities prefer using policrops and having a bit of everything for food safety and sovereignty purposes. Hence, here in the municipality, native farmers had cut ties with the Coffee Growers Committee approximately $>10$ years ago. They continued to grow coffee but in their way i.e., using their techniques of sowing and transplanting following the moon phases, ceasing agrochemical use, using organic fertilizers prepared by themselves, mixing coffee and banana, cacao, and fruits, growing coffee under shade, and performing their rituals and community acts. INotion support their decision because I understand the community's logic, which differs from the commercial farmer's rationality. This is what the Committee's farmers fail to understand" (Interview No. 19).
\end{abstract}

In this case, distancing themselves from the conventional and minimizing the alleged generic applicability of agricultural models related to the scientific-modernizing paradigm would help balance the unbalanced power relationships, albeit slightly. In this scenario, supporting the indigenous communities, which are the populations historically subjugated by the dominant culture, and protecting their way of perceiving and practicing agriculture, teaches extension agents that preserving (agro)biodiversity and traditional knowledge by supporting agriculture based on reciprocal care and (bio)coexistence, rather than a mere eminently technical decision, constitutes a political act.

Therefore, in a rural environment where the modernization model persists as a guide for agricultural policies and higher agricultural education (Méndez, 2008; Ploeg, 2010; Rodríguez-Moreno, 2014), give space to the alternative, in this case, the traditional knowledge of local natives and peasants and their agricultural practices is a practical and thoughtful act that contributes to the balance of powers. For rural extension agents whose work is mainly associated with the dissemination of a homogeneous scientific worldview among farmers and the promotion of technologies that tend to make humans less dependent on nature so that they can shape and control it (Hoefle, 2009), taking a step back from what has been learned and re-analyzing their assumptions and facts is a learning step that makes them question the dominant ideas. In this case, face-to-face interaction and a dialogue of knowledge with the native and rural communities is an opportunity to activate critical thinking and use it to unlearn what has been learned without criticism: i) that agricultural activity is primarily a business; ii) that nature is an exploitable economic resource; iii) that manipulating the natural environment to produce food and other goods is the raison d'être of agronomic knowledge; and iv) that the only rational and valid knowledge is scientific, among other hegemonic assumptions. 
As a lesson learned, for extension agents, doubting such hegemonic assumptions involves the beginning of the development of a more open way to perceive agriculture that considers the simultaneous existence of multiple conceptions regarding it. It entails the consideration that the way of guiding agricultural processes is related to the system of rules, beliefs, and values influencing each social group in particular.; that although there is a dominant model, there are several other coexisting alternatives that are worth learning about and understanding; and that conserving their notion of agriculture when the predominant concept is imposed has been a historical source of struggle for ethnic communities, such as those involved in this study.

"Today, I am personally more aware of the indigenous and peasant struggles, of their concern to keep and recover their customs and keep their territories. By being strongly associated with them, I have learned that such fights are quite logical and that by protecting the territory, they are protecting themselves as well as everything in it and everything it entails. This is not only a fight for the property of territory but the land as Mother Earth, for nature, biodiversity, the spirits of their ancestors, and their rights to food and life, because they believe agriculture produces life, rather than simply commercial goods. For these communities, preservation of their history and memory, as well as their knowledge and ancestral practices, indicate the conservation of the living. With such agricultural and ecological knowledge, they are the custodians of wild and cultivated plants, seeds, the forest, water, soil, and microorganisms. With their agricultural practices and their ecological knowledge as well as their stand against mono-crops and agriculture for the sole purpose of trading, they are the guardians of the territory and every existing being, including human, animal, and plant lives" (Interview No. 6).

Within this specific learning context, which of course is not the only possible one, rural extension agents have learned that fights to protect territory, culture, and traditional knowledge are, at the same time, fights for life preservation; that, although state policies are implemented to protect plant genetic resources and agrobiodiversity, although there are germplasm banks that conserve native and Creole species with research and productive potential (Lobo \& Medina, 2009; Valencia et al., 2010), the conservation activity would be incomplete if cultural and traditional knowledge and the physical and social area associated with these species and the communities historically cared for them and interacted and coexisted with them, are not preserved.

In this sense, within the framework of a non-antagonistic relationship between nature and culture (Sanabría \& Argueta, 2015), complementing and contributing to the preservation of knowledge, beliefs, and values related to a "caring agriculture", would be the responsibility of the agronomists and other professionals who act as agents of rural extension. Analytically speaking, this would be a task based on horizontal social interaction and constructive knowledge dialogue, aimed at fostering synergies around a less anthropocentric, utilitarian, and mechanical agricultural production practice that is increasingly vitalistic, organic, and fraternal. This work would require moving towards critical agronomy, concerned with questioning its current assumptions and events, as well as the effects of its implementation on nature, culture, and agroecosystems.

\section{Conclusions}

The interaction with indigenous-peasant communities allowed rural extension agents who provide services to traditional communities in the department of Caldas, an agronomist in principle trained within the technical-scientific paradigm, to generate the following lessons: 
* Today, they more easily understand that in the local context, agriculture, rather than a business, is a life-producing activity; that elements of nature are subjects that interact and coexist around the reproduction of life rather than objects to manipulate and appropriate; that, in practice, the scientific knowledge adopted is blended with traditional and mystic knowledge, thereby creating multicultural conservationist practices.

* They learned that, for local traditional communities, rather than a business or a source of profit, agriculture is a life creator activity. That its main purpose is the production of food, goods required to reproduce life and ensure food sovereignty. This activity is performed in harmony with other beings (either animate and inanimate) that are a part of the agroecosystem, which are perceived as subjects with whom they interact and coexist, rather than objects to appropriate and manipulate to meet human needs and desires. In such connection, the extension agents learned that agriculture based on mutual care, based on which the communion and coexistence between these beings become strengthened, would be the alternative to anthropocentric agriculture, established on nature exploitation.

* Alon the way, they discovered that, in the indigenous areas of the department of Caldas, knowledge from different backgrounds, such as traditional and scientific, converge and fuse to share a common purpose. In this case, the scientific knowledge implemented and adapted to the particulars of the local cultural context amalgamates with the mystical-sacred knowledge, originating hybrid agricultural practices around caring agriculture. Such combination was possible because of the breakdown of resistance and borders between diverse knowledge, followed by the agreement between various individuals for synergic action.

* That the fights for protecting the territory, initiated by the local native-peasant communities, rather than just claiming the property right, defend the protection of a culture associated with life conservation, including its agricultural culture. Such culture is endangered by a ruling agricultural model based on individualistic and rentier values, which are contrary to community and conservationist values, attempting to overlap others. In this context, joining the conservationist purpose has demanded that local rural extension agents carry out a critical interpretation of the values and assumptions learned throughout their professional training. This exercise, in general terms, reflectively would imply coping with the effects of the industrial agronomy practice on nature and life, taking sides for an activist agronomy practice committed to supporting agricultural, biological, and cultural diversity.

Finally, in the interest of advancing towards more socially and environmentally sustainable production models, which reflectively take a step back from the conventional model of agriculture today predominant, the experiences of the local extensionists in Caldas show a possible way forward. This consists in change the way of thinking about agriculture, conceiving it, more than just a productive activity, as a reproductive activity of life. This vision must be achieved by openness to other forms of meaning agriculture, through intercultural dialogue and reflective analysis of the results and consequences of conventional agricultural practice.

\section{References}

Agrawal, A. (1995). Dismantling the divide between indigenous and scientific knowledge. Development and Change, 26(3), 413-439.

Alarcón, P. (2016). Otras epistemologías: conocimientos y saberes locales desde el pensamiento complejo. Madrid: Editorial Académica Española. 
Alemán, T. (2016). Vivir para conocer, conocer para vivir. A propósito de campesinos y científicos. Revista LEISA, 32, 5-7.

Altieri, M., \& Nicholls, C. (2017). The adaptation and mitigation potential of traditional agriculture in a changing climate. Climatic Change, 140(1), 33-45.

Argueta, A. (1999). Contribución a los estudios etnobiológicos I. In M. Vásquez-Dávila (Ed.), La etnobiología en México: reflexiones y experiencias. Oaxaca: AEM-CONACYT.

Attride, J. (2001). Thematic networks: an analytic tool for qualitative research. Qualitative Research, 1, 385-405.

Barrasa, S., \& Reyes, F. (2011). Recuperación de saberes ambientales en comunidades campesinas en reservas de biosfera en Chiapas. In M. Panizo \& F. Reyes (Eds.), Saberes ambientales campesinos: cultura y naturaleza en comunidades indígenas y mestizas de México. Tuxtla Gutiérrez: UNICACH.

Barrera-Bassols, N., Astier, M., Orozco, Q., \& Boege, E. (2009). Saberes locales y defensa de la agrobiodiversidad: maíces transgénicos en México. Papeles, 107, 77-91.

Berger, P., \& Luckmann, T. (1979). La construcción social de la realidad. Buenos Aires: Amorrortu.

Bermúdez, O., Mayorga, M., Jacanamijoy, T., Seygundiba, Q., \& Fajardo, E. (2005). El diálogo de saberes y la educación ambiental. Bogotá: Universidad Nacional de Colombia.

Boff, L. (2005). O cuidado essencial: princípio de um novo ethos. Inclusão Social, 1, 28-35.

Briggs, J., \& Moyo, B. (2012). The resilience of indigenous knowledge in small-scale African agriculture: key drivers. Scottish Geographical Journal, 128(1), 64-80.

Brückner, G. (2006). Contrastes culturales: ¿se pueden analizar y explicar las culturas sin utilizar estereotipos. In C. Mourón \& T. Moralejo (Eds.), Studies in contrastive linguistics. Santiago de Compostela: Universidad de Santiago de Compostela.

Casey, C., \& Thomas, D. (2018). Climate change adaptation: Linking indigenous knowledge with western science for effective adaptation. Environmental Science \& Policy, 88, 83-91.

Chilón, E. (2018). La agricultura, fuentes de origen y diferencias entre los conocimientos occidental y no occidental andinos. Apthapi, 4, 1334-1364.

Clark, J., \& Murdoch, J. (1997). Local knowledge and the precarious extension of scientific networks: a reflection on three case studies. Sociologia Ruralis, 37(1), 38-60.

Consejo Regional Indígena de Caldas - CRIDEC. (2004). Plan de salvaguarda del pueblo embera de Caldas. Bogotá: CRIDEC.

Cruz, A., Cervantes, J., Damián, M., Ramírez, B., \& Chávez, P. (2015). Etnoagronomía, tecnología agrícola tradicional y desarrollo rural. Revista de Geografía Agrícola, 55, 75-89.

Cruz-León, A., Cervantes-Herrera, J., Ramírez-García, A., Sánchez-García, P., Damián-Huato, M., \& Ramírez-Valverde, B. (2015). La etnoagronomía en la construcción de propuestas de desarrollo rural para comunidades rurales. Ra Ximhai, 11, 185-194.

De Walt, B. (1994). Using indigenous Knowledge to improve agriculture and natural resource management. Human Organization, 53(2), 123-131.

Delgado, F., \& Rist, S. (2016). Las ciencias desde la perspectiva del diálogo de saberes, la transdisciplinariedad y el diálogo intercientífico. In F. Delgado \& S. Rist (Eds.), Ciencias, diálogo de saberes e interdisciplinariedad: aporte teórico metodológico para la sustentabilidad alimentaria y el desarrollo. La Paz: AGRUCO-UMSS. 
Gómez, A., \& Turbay, S. (2016). Relación de una comunidad de pescadores del golfo de Urabá (Colombia) con los sistemas de manglar y su conservación. Revista de Estudios Sociales, $55,104-119$

Granderson, A. (2017). The role of traditional knowledge in building adaptive capacity for climate change: perspectives from Vanuatu. Weather, Climate, and Society, 9(3), 545-561.

Hoefle, S. (2009). Ética ambiental, sistema agrícola e paisagem cultural na Mata Atlântica no Sudeste Brasileiro. Ateliê Geográfico, 3(3), 22-52.

Instituto Colombiano Agropecuario - ICA. (2009). Mis buenas prácticas agrícolas: guía para agroempresarios. Bogotá: ICA-CCl.

Kaup, B. (2008). The reflexive producer: the influence of farmer knowledge upon the use of Bt corn. Rural Sociology, 73(1), 62-81.

Kloppenburg, J. (1991). Social theory and the de/reconstruction of agricultural science: local knowledge for an alternative agriculture. Rural Sociology, 56(4), 519-548.

Kottak, C. (1999). The new ecological anthropology. American Anthropologist, 101, $23-35$.

Lehébel-Péron, A., Sidawy, P., Dounias, E., \& Schatz, B. (2016). Attuning local and scientific knowledge in the context of global change: The case of heather honey production in southern France. Journal of Rural Studies, 44, 132-142.

Lobo, M., \& Medina, C. (2009). Conservación de recursos genéticos de la agrobiodiversidad como apoyo al desarrollo de sistemas de producción sostenibles. Corpoica Ciencia y Tecnología Agropecuaria, 10, 33-42.

Mapfumo, P., Mtambanengwe, F., \& Chikowo, R. (2016). Building on indigenous knowledge to strengthen the capacity of smallholder farming communities to adapt to climate change and variability in southern Africa. Climate and Development, 8(1), 72-82.

Méndez, M. (2008). Integración del componente sociohumanístico en la formación de profesionales en ciencias agropecuarias: percepciones, propósitos y desafíos. Revista Facultad Nacional de Agronomía, 61(2), 4471-4479.

Meo, A., \& Navarro, A. (2009). La voz de los otros. El uso de la entrevista en la investigación social. Buenos Aires: Oicom System.

Molnar, J., Duffy, P., Cummins, K., \& Van Santen, E. (1992). Agricultural science and agricultural counterculture: paradigms in search of a future. Rural Sociology, 57(1), 83-91.

Moschitz, H., Roep, D., Brunori, G., \& Tisenkopfs, T. (2015). Learning and innovation networks for sustainable agriculture: processes of co-evolution, joint reflection and facilitation. Journal of Agricultural Education and Extension, 21(1), 1-11.

Núñez, J. (2004). Los saberes campesinos: implicaciones para una educación rural. Investigación y Postgrado, 19, 1-19.

Nyong, A., Adesina, F., \& Osman, B. (2007). The value of indigenous knowledge in climate change mitigation and adaptation strategies in the African Sahel. Mitigation and Adaptation Strategies for Global Change, 12(5), 787-797.

Panizo, M., \& Perdomo, A. (2017). Recopilando y compartiendo el conocimiento ecológico tradicional. Revista Agroecológica de Divulgación, 28, 52-54.

Pavón, M. (2014). Extensionismo en Cuba: estudios de caso. Cultivos Tropicales, 35, 5-10.

Pawluk, R., Sandor, J., \& Tabor, J. (1992). The role of indigenous soil knowledge in agricultural development. Journal of Soil and Water Conservation, 47(4), 298-302. 
Ploeg, J. (2010). Nuevos campesinos: campesinos e imperios alimentarios. Madrid: Icaria.

Raymond, C., Fazey, I., Reed, M., Stringer, L., Robinson, G., \& Evely, A. (2010). Integrating local and scientific knowledge for environmental management. Journal of Environmental Management, 91(8), 1766-1777.

Rodríguez-Moreno, J. (2014). Elementos de la praxis y del corpus del conocimiento etnoecológico tzeltal en comunidades de la Sierra Norte de Chiapas. Revista LiminaR, 12, 92-102.

Roland, B., Rubens, A., \& Akolgo, A. (2018). Combining indigenous wisdom and academic knowledge to build sustainable future: an example from rural Africa. Journal of African Studies and Development, 10(2), 8-18.

Rosset, P. (2015). Epistemes rurales y la formación agroecológica en la Vía Campesina. Revista Ciencia \& Tecnología Social, 2, 4-13.

Sanabría, O., \& Argueta, A. (2015). Cosmovisiones y naturalezas en tres culturas indígenas de Colombia. Etnobiología, 13, 5-20.

Sánchez, M. (2017). Comprender la agricultura en los Andes Peruanos: religión en la comunidad de Yanque (Caylloma, Arequipa). Revista Peruana de Antropología, 2, 9-19.

Souza, B. (2009). Una epistemología del sur. México: CLACSO-Siglo XXI.

Sumane, S., Kunda, I., Knickel, K., Strauss, A., Tisenkopfs, T., Des Los Ríos, I., Rivera, M., Chebach, T., \& Ashkenazy, A. (2018). Local and farmers' knowledge matters! How integrating informal and formal knowledge enhances sustainable and resilient agriculture. Journal of Rural Studies, 59, 232-241.

Swartley, L. (2018). Inventing indigenous knowledge: archaeology, rural development and the raised field rehabilitation project in Bolivia. New York: Routledge

Tisenkopfs, T., Kunda, I., Sumane, S., Brunori, G., Klerkx, L., \& Moschitz, H. (2015). Learning and innovation in agriculture and rural development: the use of the concepts of boundary work and boundary objects. Journal of Agricultural Education and Extension, 21(1), 13-33.

Toledo, V. (2005). La memoria tradicional: la importancia agroecológica de los saberes locales. Revista LEISA, 20, 16-19.

Toledo, V., Ortiz-Espejel, B., Cortés, L., Moguel, P., \& Ordoñez, M. (2003). The multiple use of tropical forests by indigenous peoples in Mexico: a case of adaptive management. Conservation Ecology, 7(3), art9. http://dx.doi.org/10.5751/ES-00524-070309

Valencia, R., Lobo, M., \& Ligarreto, G. (2010). Estado del arte de los recursos genéticos vegetales en Colombia: Sistema de Bancos de Germoplasma. Corpoica Ciencia y Tecnología Agropecuaria, 11, 85-94.

Van Kessel, J., \& Enríquez, P. (2002). Señas y señaleros de la Santa Tierra. Agronomía Andina. Quito: Abya-Yala.

Vía Campesina. (2013). De Maputo a Yakarta: 5 años de agroecología en La Vía Campesina Vía Campesina. Retrieved in 2019, February 17, from https://viacampesina.org/es/wp-content/ uploads/sites/3/2013/07/De-Maputo-a-Yakarta-ES web.pdf

Villalobos, F., Mateos, L., \& Orgaz, F. (2009). Fitotecnia: bases y tecnologías de la producción agrícola. Madrid: Ediciones Mundi-Prensa.

Walsh, C. (2009). Interculturalidad crítica y pedagogía de-colonial: apuestas (des)de el in-surgir, re-exisitiry re-vivir. Retrieved in 2020, October 21, from https://www.maxwell.vrac.puc-rio. $\mathrm{br} / 13582 / 13582 . P D F$ 
Wang, Z., Liu, J., Xu, N., Fan, C., Fan, Y., He, S., Jiao, L., \& Ma, N. (2019). The role of indigenous knowledge in integrating scientific and indigenous knowledge for community-based disaster risk reduction: a case of Haikou Village in Ningxia, China. International Journal of Disaster Risk Reduction, 41, 101309. http://dx.doi.org/10.1016/j.ijdrr.2019.101309 